\title{
In Vitro Antibacterial Activities of Various Ethanolic Medicinal Plant Extracts Against Some Human Pathogenic Bacteria
}

\author{
Samir K. Ali ${ }^{1, a}$, Ghorbat S. Ali ${ }^{1, b}$, Berivan A. Abdullah ${ }^{1, c, *}$ \\ ${ }^{I}$ Department of Biology, College of Science, University of Duhok, Duhok, Iraq \\ *Corresponding author

A R T I C L E IN F O A B S T R A C T \\ Research Article \\ The widespread use of antibiotics often causes increase in the bacterial drugs resistance and causes \\ many side effects in humans. Medical plants have antimicrobial effects against most pathogenic \\ bacteria and can serve as harmless replacement to antibiotics. The aim of this study was to assess the \\ antibacterial effect of five medicinal plant prevailed in Kurdistan region namely; Cinnamon \\ Received : 26/12/2019 \\ Accepted : 16/03/2020 \\ (Cinnamomum cassia (L.) D.Don), Nigella (Nigella sativa L.), Allium (Allium hirtifolium Boiss.), \\ Carrot (Daucus carota L.), and Fennel (Foeniculum vulgare Mill.) against pathogenic Gram positive \\ bacteria (Staphylococcus aureus), and pathogenic Gram negative bacteria (Salmonella typhi and \\ Escherichia coli). The evaluation of antibacterial activity for these plant extracts was carried out \\ using agar-well diffusion method. Results showed that minimum inhibitory concentration (MIC) of \\ A. hirtifolium against tested bacterial isolates were $(25 \mathrm{mg} / \mathrm{mL})$, the lowest MIC values for $S$. aureus \\ Keywords: \\ were $(25 \mathrm{mg} / \mathrm{mL})$ observed with $C$. cassia, $N$. sativa and $F$. vulgare ethanolic extracts and the lowest \\ Antibacterial activity \\ Ethanol plant extract \\ S. typhi \\ E. coli \\ MIC of $D$. carota against bacterial isolates were $(50 \mathrm{mg} / \mathrm{mL})$, Also, it was observed that $S$. aureus \\ was more sensitive than $S$. typhi and $E$. coli to plant extracts. The ethanol plant extracts had potential \\ antibacterial activities. However, further studies are required to identify the active compounds which \\ Iraq \\ could be used for the preparation of new antimicrobial agents and control the bacterial infectious \\ diseases.
}

\section{Introduction}

Bacterial infectious diseases are one of the health disorders and they will continue to emerge and probably increase. According to recent estimates, Salmonella typhi, Staphylococcus aureus and Escherichia coli causing several hundred million cases of infections low-and middle-income countries (Tong et al., 2015; Als et al., 2018; Khalil et al., 2018). These agents were reported with high rates in Iraq (Assafi et al., 2015; Polse et al., 2016; Allu et al., 2019). Furthermore, these pathogens were reported with increasing rates of antibiotic resistance (Assafi et al., 2017; Akreyi et al., 2018; Hussein et al., 2018). Recently, antibiotic-resistant bacteria become a main problem due to fail respond to conventional treatments (Zeedan et al., 2016). Therefore, it is essential to search for other alternative treatments that can potentially be useful in the treatment of these problematic infections (Bocanegra-Garcia et al., 2009). Therefore, medicinal plants have been widely used as one of the alternative medicines against various infections (Buwa and van Staden, 2006; Sevindik et al., 2017). Medicinal herb plants have antioxidant properties and low side effects compared to chemical drugs (Karimi et al., 2015; Pehlivan et al., 2018; Mohammed et al., 2019). The antimicrobial activity of various plant extracts against many microorganisms were investigated and found to be effective against almost all bacterial species (Burt and Reinders, 2003; Elisha et al., 2017; Pehlivan and Sevindik, 2018). The aim of this study was to investigate the antibacterial activities of five selected medicinal plants against three clinical bacterial isolates, S. typhi, S. aureus and E. coli, in Duhok city, Iraq.

\section{Materials and Methods}

\section{Ethanolic Plant Extract}

Powder material of Cinnamon, seed powders of Nigella, bulbs of Alliums, Carrot seeds, and Fennel seeds were obtained from Duhok farms and markets. The plant materials were then cleaned and dried using drying cabinet under $40^{\circ} \mathrm{C}$ for $3-4$ days, then the seeds were grinded into powder form and Alliums bulbs were sliced into small pieces and then used. One hundred grams of each plant 
were mixed with one litter of the $80 \%$ ethanol extraction fluid; the mixture was kept in tightly sealed vessels at room temperature. Then, the mixture filtrated through muslin cloth and evaporated till dryness under reduced pressure. The extract was stored in cans and kept in a refrigerator at $4^{\circ} \mathrm{C}$. After that, different concentrations $(25,50,75,100$ $\mathrm{mg} / \mathrm{mL}$ ) of each plant extract was prepared and subjected to antibacterial activity (AL-Saghir et al., 2009; Hosseinzadeh et al., 2013; Akha et al., 2014).

\section{Bacterial Species Used}

The pathogenic species used in the present study were clinical isolates of $S$. aureus, S. typhi and E. coli, which were previously isolated and identified in department of Biology / College of Science / University of Duhok.

\section{The Antibacterial Sensitivity Tests}

The antibacterial activity of prepared five plants extracts was tested against three pathogenic bacteria species using agar-well diffusion method. Mueller Hinton agar medium was prepared and inoculated with $50 \mu \mathrm{L}$ of each of bacterial suspension (with optical density 0.1 at 450 $\mathrm{nm}$ wavelength using spectrophotometer). For each plate, a hole (well) of $6 \mathrm{~mm}$ in diameter was made using cork borer and filled with $100 \mu \mathrm{L}$ of the desired plant extract concentration and incubated at $37^{\circ} \mathrm{C}$ for 24 hours. Sterilized distilled water has been used as control. After the incubation period, the inhibition zone was measured and the minimum inhibitory concentration was estimated as the lowest concentration of the plant extract used that will inhibit the visible growth of bacteria. All tests were achieved in duplicated (Turkoglu et al., 2007).

\section{Results}

A total of five ethanolic plant extracts were investigated in this study. The tested plants varied in their antibacterial activities against $S$. typhi, S. aureus and E. coli. The inhibition zone of all plant extracts concentration for all pathogens was measured (Table 1). Sterilized distilled water was used as control that showed no any inhibition zone against tested bacterial species.

The plant extracts showed different inhibition in bacterial growth of $S$. aureus, $S$. typhi and E. coli depending on the concentration used. The lowest concentrations $(25 \mathrm{mg} / \mathrm{mL})$ of, $C$. cassia, N. sativa, $F$. vulgare and $D$. carota extracts was ineffective against the pathogens, while the lowest concentration of A. hirtifolium extract $(25 \mathrm{mg} / \mathrm{mL})$ was effective against these bacterial species (Table 1-2). All plant extracts showed more potent activity against $S$. aureus than $S$. typhi and E. coli except A. hirtifolium extract, which exhibit mostly equal effectiveness against $S$. aureus, $S$. typhi and E. coli. Compared with other plants extracts, the highest effects against all pathogens were observed in the A. hirtifolium extracts (Table 1).

\section{Discussion}

Global prevalence of bacterial infectious diseases is a major public health problem (Sevindik, 2018). High prevalence rates of $S$. typhi, S. aureus and E. coli with high antibiotic resistance now documented worldwide and particularly in Iraq (Habeeb et al., 2014; Akreyi et al., 2018). The global rise in antibiotic resistance is growing and it is vary by location, organism, and antibiotic (Aslam et al., 2018). The microbial antibiotic resistance is due to the several factors, especially the high exposure to antibiotics. Also, the exposure to antibiotics can disrupt the gut microflora leading to dysbiosis of the microbial community, and opening niches for other pathogens to proliferate (Yoon and Yoon, 2018). Therefore, medicinal plants have been widely used as alternative medicine against the infectious diseases. The era of medicinal plants is not new, it was used even before the era of discovery the antibiotics. However, there has been a decline in botanical compounds used in medicine.

This study revealed the effectiveness of five ethanolic plant extracts including C. cassia, N. sativa, A. hirtifolium, $D$. carota and $F$. vulgare against $S$. aureus (pathogenic Gram-positive bacteria) and $S$. typhi and E. coli (pathogenic Gram-negative bacteria). The extracts showed antibacterial activity to tested microorganisms with different MIC values from $25-75 \mathrm{mg} / \mathrm{mL}$. S. aureus was more susceptible to most plant extracts compared with $S$. typhi and E. coli. This is could be attributed to the presence of the outer membrane carrying the structural lipopolysaccharide (LPS) in Gram-negative bacteria, while Gram-positive bacteria should be more susceptible as these bacteria have only peptidoglycan layer that is not effective permeability barrier (Nostro et al., 2000; Derbal and Niar, 2019).

Cinnamomum is a genus belongs to Lauraceae family, which is cultivated in many tropical countries (Fei et al., 2011). Medicinally important bioactive material of cinnamon found in its leaves, fruits inner and outer bark. Much of bioactivity materials of cinnamon reside in its oil, which is approximately $90 \%$ cinnamaldehyde. It is used chiefly in medicine, foods and cosmetics (Nabawi et al., 2015). C. cassia is widely applied in digestive complaints such as dyspepsia, gastritis, flatulence, diarrhea and vomiting (Ranasinghe et al., 2013). Several publications have demonstrated the antibacterial activity of cinnamon against various pathogens (Gill and Holley, 2004; Shan et al., 2007). Ethanol extract of C. cassia has shown to have strong activity against oral pathogen for Streptococcus mutans and Streptococcus sanguinis. In a study, minimum inhibitory concentration for growth inhibition was at 4 $\mathrm{mg} / \mathrm{mL}$ concentration for anti-caries bacteria (Kim and Park, 2017).

The present study revealed that the lowest variation was observed in Alliums extract with MIC value of $25 \mathrm{mg} / \mathrm{mL}$ against the three tested bacterial species. Also, Alliums extract produced inhibition zones ranged $12-34 \mathrm{~mm}, 6-31 \mathrm{~mm}$ and 6.5-31 for $S$. aureus $S$. typhi and E. coli, respectively. The findings of this study are in agreement with the earlier research that showed that the gram-positive bacteria (Enterococcus faecalis) inhibited its growth with $10 \mathrm{mg} / \mathrm{mL}$ of Alliums (Satvati et al., 2017). This could be due to its strong antimicrobial effects because it contains phenolic, flavonoid, and antioxidant compounds (Leelarungrayub et al., 2006). Also, this antibacterial activity could be due to different fatty acids and other organic components of this plant (Asgarpanah and Ghanizadeh, 2012). Moreover, studies have identified medical compounds in the A. hirtifolium bulbs such as 
linolenic, linoleic, palmitoleic, palmitic, oleic and stearic acids, kaempferol, quercetin, shallomin furostanal, spirostanal, thiosulfinates, and flavonoids (Amin et al., 2012).

Table 1. Antibacterial activity (inhibition zone/mm) of ethanol extract against $S$. aureus, S. typhi and E. coli.

\begin{tabular}{l|rccc}
\hline \multicolumn{1}{c|}{ Plants } & Conc. $(\mathrm{mg} / \mathrm{mL})$ & S. aureus & S. typhi E. coli \\
\hline \multirow{4}{*}{ C. cassia } & 25 & 4 & - & - \\
& 50 & 12 & - & 7 \\
& 75 & 15 & 6 & 10 \\
& 100 & 22 & 8 & 15 \\
\hline \multirow{5}{*}{ hirtifolium } & 25 & 12 & 6 & 6.5 \\
& 50 & 19.5 & 11.5 & 11 \\
& 75 & 23 & 18 & 19 \\
N. sativa & 100 & 34 & 31 & 31 \\
\hline \multirow{5}{*}{ F. vulgare } & 25 & 4 & - & - \\
& 50 & 9 & 3 & 7.5 \\
& 75 & 11 & 6.5 & 12 \\
& 100 & 16.5 & 11 & 19 \\
\hline \multirow{5}{*}{ D. carota } & 25 & 3.5 & - & - \\
& 50 & 10.5 & 5 & 5.5 \\
& 75 & 14 & 7 & 9 \\
& 100 & 19 & 8 & 11 \\
\hline & 25 & - & - & - \\
& 50 & 11 & 9 & 6 \\
& 75 & 16 & 14 & 8 \\
& 100 & 20 & 16 & 14 \\
\hline
\end{tabular}

Table 2. Minimum inhibitory concentrations $(\mathrm{mg} / \mathrm{mL})$ of ethanolic plant extract against $S$. aureus, S. typhi and E. coli

\begin{tabular}{l|ccc}
\multicolumn{1}{c|}{ Plants } & S. aureus & S. typhi & E. coli \\
\hline Cinnamon & 25 & 75 & 50 \\
Alliums & 25 & 25 & 25 \\
Nigella & 25 & 50 & 50 \\
Fennel & 25 & 50 & 50 \\
Carrot & 50 & 50 & 50 \\
\hline
\end{tabular}

A. hirtifolium has been shown to have various pharmacological compounds responsible for the antimicrobial, anticancer and anti-inflammatory (Azadi et al., 2008; Ghahremani-majd et al., 2012). Ismail et al. (2013) revealed that $A$. hirtifolium hydromethanolic extract inhibited the growth of 10 different species of pathogenic bacteria and the minimum concentration was $1.88 \mathrm{mg} / \mathrm{mL}$ for most of the pathogenic Gram-positive bacteria.

Black cumin is a plant that is grown worldwide. For a long history, $N$. sativa plants have been used in many cultures for the treatment of many infectious diseases (Ahmad and Beg, 2013). In the current study, E. coli was the most sensitive pathogen toward the $N$. sativa plant extract. The seeds of this plant contain linoleic, oleic and palmitic and 11, 14-cis, cis-eicosadienoic acids. N. sativa seed extract contains active pharmaceutical components such as predominantly of the monoterpenes p-cymene, $\gamma$ terpinene, $\alpha$-pinene, $\beta$-pinene, $\alpha$-thujene, carvacrol and thymoquinone which have potential medicinal properties (Benkaci-Ali et al., 2007). Moreover, its extract has several beneficial biological effects including as anticancer, immunomodulatory antihypertensive, liver and renal protective, anti-diarrheal, appetite stimulant, and analgesics, antimicrobial properties (Ahmad et al., 2013). Khan and Kou (2016) detected that the Ethanol and n- hexane extracts of the $N$. sativa acting against different strains of Gram-positive and Gram-negative bacteria.

Fennel, a plant is belonging to the family Apiaceae, has been used for disturbance of endocrine, digestive, reproductive, and respiratory systems (Badgujar et al., 2014). The susceptibility of all pathogens toward $F$. vulgare was varied according to the concentrations. Several compounds were identified in this plant include the flavonoids, polyphenols, carotenoids, minerals and vitamins. Estragole, fenchone, alpha-phellandrene and aglycons present in the fruit of $F$. vulgare (Fang et al., 2006). A series of studies showed that $F$. vulgare effectively kills the various bacteria or fungal and viral cells (Rather et al., 2016). Kwon et al. (2002) investigated that secondary metabolites present in the $F$. vulgare seed extracts is correlated to inhibition of the growth of Acinetobacter baumannii which was as multidrug resistant bacteria. Another study performed by Roby et al. (2013) was revealed that the methanol, ethanol, diethyl ether, and hexane extracts of $F$. vulgare seeds bactericide two Gram negative bacterial species ( $S$. typhi and E. coli) and Gram-positive bacteria species (S. aureus and B. cereus).

Daucus common name carrot, is a genus of herbaceous plants belongs to family Apiaceae (Ahmed et al., 2005). The ethanolic extract of $D$. carota showed similar effectiveness against the three tested bacterial species with MIC value of $(50 \mathrm{mg} / \mathrm{mL})$. This result is in agreement with previous study of (Soković et al., 2009). Nowadays, the vegetable root of the species $D$. carota is widely used for both food and natural therapy purposes (da Silva Dias, 2014). Carrots are one of the rich sources of vitamin A, as well as flavonoids, phenols, involving caffeic, chlorogenic and p-hydroxybenzoic acids along with many cinnamic acid derivates, and chlorogenic and hydroxycinnamic acids (Gonçalves et al., 2010).

Plants produce several compounds known as secondary metabolites, such as tannins, terpenoids, alkaloids, and flavonoids, are used for the treatment of health disorders (Wink, 2015). These compounds are not necessary for the plant growth and function, but they release these chemical signals into their environment for the purposes of communication and defense.

\section{Conclusion}

In conclusion, our results revealed potent antimicrobial properties of five tested plant extracts against tested bacterial isolates, especially $S$. aureus. Alliums ethanolic extract has the highest potentially antibacterial properties against tested bacterial isolates. The ethanol extracts of the different plant were found to have potential antibacterial activities. Further studies are required to investigate the active compound of each part of these plants. These compounds could then be recommended as source of pharmaceutical materials required for the preparation of new antimicrobial agents which can lead to control the bacterial infectious diseases.

\section{References}

Ahmad A, Husain A, Mujeeb M, Khan SA, Najmi AK, Siddique NA, Damanhouri ZA, Anwar F. 2013. A review on therapeutic potential of Nigella sativa: A miracle herb. Asian Pac J Trop Biomed, 3: 337-52. 
Ahmad S, Beg ZH. 2013. Hypolipidemic and antioxidant activities of thymoquinone and limonene in atherogenic suspension fed rats. Food Chem, 138: 1116-24.

Ahmed AA, Bishr MM, El-Shanawany MA, Attia EZ, Ross SA, Pare PW. 2005. Rare trisubstituted sesquiterpenes daucanes from the wild Daucus carota. Phytochemistry, 66: 1680-4.

Akha O, Rabiei K, Kashi Z, Bahar A, Zaeif-Khorasani E, Kosaryan M, Saeedi M, Ebrahimzadeh MA, Emadian O. 2014. The effect of fennel (Foeniculum vulgare) gel 3\% in decreasing hair thickness in idiopathic mild to moderate hirsutism, A randomized placebo controlled clinical trial. Caspian J Intern Med, 5: 26-9.

Akreyi WHS, Yousif SY, Assafi MS. 2018. Antibiotic resistant and plasmid conjugative study of Salmonella typhi. Jurnal Teknologi Laboratorium, 7: 38-45.

AL-Saghir MG, Babaei M, Abarghoei ME, Ansari R, Vafaei AA, Taherian AA. 2009. Antibacterial assay of Cinnamomum cassia (Nees and Th. Nees) Nees ex blume bark and Thymus vulgaris L. leaf extracts against five pathogens. Journal of Biological Sciences, 9: 280-2.

Allu MA, Assafi MS, Polse RF, Al-Berfkani MI. 2019. Present status of Salmonella typhi in different age groups hospitalized patients in Duhok City, Iraq. ZJPAS, 31: 123-29.

Als D, Radhakrishnan A, Arora P, Gaffey MF, Campisi S, Velummailum R, Zareef F, Bhutta ZA. 2018. Global Trends in Typhoidal Salmonellosis: A Systematic Review. Am J Trop Med Hyg, 99: 10-19.

Amin M, Pipelzadeh MH, Mehdinejad M, Rashidi I. 2012. An in vivo toxicological study upon shallomin, the active antimicrobial constitutes of Persian shallot (Allium hirtifolium, Boiss) extract. Jundishapur journal of natural pharmaceutical products, 7: 17.

Asgarpanah J, Ghanizadeh B. 2012. Pharmacologic and medicinal properties of Allium hirtifolium Boiss. African Journal of Pharmacy and Pharmacology, 6: 1809-14.

Aslam B, Wang W, Arshad MI, Khurshid M, Muzammil S, Rasool MH, Nisar MA, Alvi RF, Aslam MA, Qamar MU, Salamat MKF, Baloch Z. 2018. Antibiotic resistance: a rundown of a global crisis. Infect Drug Resist, 11: 1645-58.

Assafi MS, Ibrahim NMR, Hussein NR, Taha AA, Balatay AA. 2015. Urinary Bacterial Profile and Antibiotic Susceptibility Pattern among Patients with Urinary Tract Infection in Duhok City, Kurdistan Region, Iraq. Int. J. Pure Appl. Sci. Technol., 30: 54-63.

Assafi MS, Polse RF, Hussein NR, Haji AH, Issa AR. 2017. The Prevalence of $S$. aureus Nasal Colonisation and its Antibiotic Sensitivity Pattern amongst Primary School Pupils. Science Journal of University of Zakho, 5: 7-10.

Azadi HG, Ghaffari SM, Riazi GH, Ahmadian S, Vahedi F. 2008. Antiproliferative activity of chloroformic extract of Persian Shallot, Allium hirtifolium, on tumor cell lines. Cytotechnology, 56: 179-85.

Badgujar SB, Patel VV, Bandivdekar AH. 2014. Foeniculum vulgare Mill: a review of its botany, phytochemistry, pharmacology, contemporary application, and toxicology. Biomed Res Int, 2014: 842674.

Benkaci Ali F, Baaliouamer A, Meklati BY, Chemat F. 2007. Chemical composition of seed essential oils from Algerian Nigella sativa extracted by microwave and hydrodistillation. Flavour and fragrance journal, 22: 148-53.

Bocanegra-Garcia V, Del Rayo Camacho-Corona M, RamirezCabrera M, Rivera G, Garza-Gonzalez E. 2009. The bioactivity of plant extracts against representative bacterial pathogens of the lower respiratory tract. BMC Res Notes, 2: 95.

Burt SA, Reinders RD. 2003. Antibacterial activity of selected plant essential oils against Escherichia coli O157:H7. Lett Appl Microbiol, 36: 162-7.

Buwa LV, van Staden J. 2006. Antibacterial and antifungal activity of traditional medicinal plants used against venereal diseases in South Africa. J Ethnopharmacol, 103: 139-42. da Silva Dias JC. 2014. Nutritional and health benefits of carrots and their seed extracts. Food and Nutrition Sciences, 5: 2147.

Derbal S, Niar A. 2019. Antibacterial activity of honey and Nigella sativa L. seed extracts against animal wound bacteria. International journal of Veterinary Science and research, 5: 030-34.

Elisha IL, Botha FS, McGaw LJ, Eloff JN. 2017. The antibacterial activity of extracts of nine plant species with good activity against Escherichia coli against five other bacteria and cytotoxicity of extracts. BMC Complement Altern Med, 17: 133.

Fang L, Qi M, Li T, Shao Q, Fu R. 2006. Headspace solvent microextraction-gas chromatography-mass spectrometry for the analysis of volatile compounds from Foeniculum vulgare Mill. J Pharm Biomed Anal, 41: 791-7.

Fei LU, Ding YC, YE XQ, Ding YT. 2011. Antibacterial effect of cinnamon oil combined with thyme or clove oil. Agricultural Sciences in China, 10: 1482-87.

Ghahremani-majd H, Dashti F, Dastan D, Mumivand H, Hadian J, Esna-Ashari M. 2012. Antioxidant and antimicrobial activities of Iranian mooseer (Allium hirtifolium Boiss) populations. Horticulture, Environment, and Biotechnology, 53: 116-22.

Gill AO, Holley RA. 2004. Mechanisms of bactericidal action of cinnamaldehyde against Listeria monocytogenes and of eugenol against L. monocytogenes and Lactobacillus sakei. Appl Environ Microbiol, 70: 5750-5.

Gonçalves EM, Pinheiro J, Abreu M, Brandão TRS, Silva CL. 2010. Carrot (Daucus carota L.) peroxidase inactivation, phenolic content and physical changes kinetics due to blanching. Journal of Food Engineering, 97: 574-81.

Habeeb A, Hussein NR, Assafi MS, Al-Dabbagh SA. 2014. Methicillin resistant Staphylococcus aureus nasal colonization among secondary school students at Duhok City-Iraq. J Microbiol Infect Dis, 4: 59-63.

Hosseinzadeh H, Tafaghodi M, Mosavi MJ, Taghiabadi E. 2013. Effect of aqueous and ethanolic extracts of Nigella sativa seeds on milk production in rats. J Acupunct Meridian Stud, 6: 18-23.

Hussein NR, Daniel S, Salim K, Assafi MS. 2018. Urinary Tract Infections and Antibiotic Sensitivity Patterns Among Women Referred to Azadi Teaching Hospital, Duhok, Iraq. Avicenna journal of clinical microbiology and infection, 5: 27-30.

Ismail S, Jalilian FA, Talebpour AH, Zargar M, Shameli K, Sekawi Z, Jahanshiri F. 2013. Chemical composition and antibacterial and cytotoxic activities of Allium hirtifolium Boiss. Biomed Res Int, 2013: 696835.

Karimi A, Majlesi M, Rafieian-Kopaei M. 2015. Herbal versus synthetic drugs; beliefs and facts. J Nephropharmacol, 4: 27-30.

Khalil IA, Troeger C, Blacker BF, Rao PC, Brown A, Atherly DE, Brewer TG, Engmann CM, Houpt ER, Kang G, Kotloff KL, Levine MM, Luby SP, MacLennan CA, Pan WK, Pavlinac PB, Platts-Mills JA, Qadri F, Riddle MS, Ryan ET, Shoultz DA, Steele AD, Walson JL, Sanders JW, Mokdad AH, Murray CJL, Hay SI, Reiner RC, Jr. 2018. Morbidity and mortality due to Shigella and enterotoxigenic Escherichia coli diarrhoea: The Global Burden of Disease Study 1990-2016. Lancet Infect Dis, 18: 1229-40.

Khan AR, Kour K. 2016. Wide spectrum antibacterial activity of Nigella sativa L. seeds. IOSR Journal of Pharmacy, 7: 12-16.

Kim HY, Park JB. 2017. In vitro evaluation of anti-caries effect of cinnamon extracts on oral pathogens. Biomedical Research, 28: 2848-53.

Kwon YS, Choi WG, Kim WJ, Kim WK, Kim MJ, Kang WH, Kim CM. 2002. Antimicrobial constituents of Foeniculum vulgare. Arch Pharm Res, 25: 154-7.

Leelarungrayub N, Rattanapanone V, Chanarat N, Gebicki JM. 2006. Quantitative evaluation of the antioxidant properties of garlic and shallot preparations. Nutrition, 22: 266-74. 
Mohammed FS, Daştan T, Sevindik M, Selamoglu Z. 2019. Antioxidant, antimicrobial activity and therapeutic profile of Satureja hortensis from Erzincan Province. Cumhuriyet Tip Dergisi, 41(3): 558-562.

Nabavi SF, Di Lorenzo A, Izadi M, Sobarzo-Sanchez E, Daglia M, Nabavi SM. 2015. Antibacterial Effects of Cinnamon: From Farm to Food, Cosmetic and Pharmaceutical Industries. Nutrients, 7: 7729-48.

Nostro A, Germano MP, D'Angelo V, Marino A, Cannatelli MA. 2000. Extraction methods and bioautography for evaluation of medicinal plant antimicrobial activity. Lett Appl Microbiol, 30: 379-84.

Pehlivan M, Sevindik M. 2018. Antioxidant and antimicrobial activities of Salvia multicaulis. Turkish Journal of Agriculture-Food Science and Technology, 6(5): 628-631.

Pehlivan M, Mohammed FS, Sevindik M, Akgul H. 2018. Antioxidant and oxidant potential of Rosa canina. Eurasian Journal of Forest Science, 6(4): 22-25.

Polse RF, Yousif SY, Assafi MS. 2016. Prevalence and molecular characterization of extended spectrum beta-Lactamasesproducing uropathogenic Escherichia coli isolated in Zakho, Iraq. Journal of Microbiology and Infectious Diseases, 6: 163-67.

Ranasinghe P, Pigera S, Premakumara GS, Galappaththy P, Constantine GR, Katulanda P. 2013. Medicinal properties of 'true'cinnamon (Cinnamomum zeylanicum): a systematic review. BMC complementary and alternative medicine, 13: 275

Rather MA, Dar BA, Sofi SN, Bhat BA, Qurishi MA. 2016. Foeniculum vulgare: A comprehensive review of its traditional use, phytochemistry, pharmacology, and safety. Arabian Journal of Chemistry, 9: S1574-S83.

Roby MHH, Sarhan MA, Selim KAH, Khalel KI. 2013. Antioxidant and antimicrobial activities of essential oil and extracts of fennel (Foeniculum vulgare L.) and chamomile (Matricaria chamomilla L.). Industrial crops and products, 44: 437-45.
Satvati SAR, Shooriabi M, Amin M, Shiezadeh F. 2017. Evaluation of the Antimicrobial Activity of Tribulus terrestris, Allium sativum, Salvia officinalis, and Allium hirtifolium Boiss Against Enterococcus faecalis. International Journal of Enteric Pathogens, 5: 63-67.

Sevindik M. 2018. Antioxidant and antimicrobial activity of Cerrena unicolor. Mycopath, 16(1): 11-14.

Sevindik M, Akgul H, Pehlivan M, Selamoglu Z. 2017. Determination of therapeutic potential of Mentha longifolia ssp. longifolia. Fresen Environ Bull, 26(7): 4757-4763.

Shan B, Cai YZ, Brooks JD, Corke H. 2007. Antibacterial properties and major bioactive components of cinnamon stick (Cinnamomum burmannii): activity against foodborne pathogenic bacteria. J Agric Food Chem, 55: 5484-90.

Soković M, Stojković D, Glamočlija J, Ćirić A, Ristić M, Grubišić D. 2009. Susceptibility of pathogenic bacteria and fungi to essential oils of wild Daucus carota. Pharmaceutical Biology, 47: 38-43.

Tong SY, Davis JS, Eichenberger E, Holland TL, Fowler VG, Jr. 2015. Staphylococcus aureus infections: epidemiology, pathophysiology, clinical manifestations, and management. Clin Microbiol Rev, 28: 603-61.

Türkoğlu A, Duru ME, Mercan N. 2007. Antioxidant and antimicrobial activity of Russula delica Fr: An Edidle wild mushroom. Eurasian journal of analytical chemistry, 2: 54-67.

Wink M. 2015. Modes of Action of Herbal Medicines and Plant Secondary Metabolites. Medicines (Basel), 2: 251-86.

Yoon MY, Yoon SS. 2018. Disruption of the Gut Ecosystem by Antibiotics. Yonsei Med J, 59: 4-12.

Zeedan GS, Alharbi SA, Abdalhamed AM, Khatar ES. 2016. Antimicrobial Effect of Honey and Some Herbal Plant Extracts Against Multidrug Resistance Bacteria Isolated from Patient in Local Riyadh Hospital. International Journal of Advanced Research, 4: 283-91. 